\title{
Therapeutic Challenges in the Management of Acute Myocardial Infarction in Polycythemia Vera
}

\section{Ramya Thota*}

Clinical Fellow, Division of Hematology-Oncology, Vanderbilt University Medical Center, Nashville, Tennessee, USA

*Corresponding author: Ramya Thota, Clinical Fellow, Division of Hematology-Oncology, Vanderbilt University Medical Center, Nashville, Tennessee, USA, Tel: 615-322-4967; E-mail: ramyathota1@gmail.com

Received date: Jan 24, 2015, Accepted date: Feb 11, 2015, Publication date: Feb 14, 2015

Copyright: (c) 2015 Thota R. This is an open-access article distributed under the terms of the Creative Commons Attribution License, which permits unrestricted use, distribution, and reproduction in any medium, provided the original author and source are credited.

\section{Introduction}

Polycythemia rubra vera (PV) is a chronic myeloproliferative disorder characterized by elevated red cell mass with an increased risk of both thrombosis and bleeding. Thromboembolic events are the most significant and life-threatening complications associated with PV [1]. Here, we report a rare case of PV presenting as acute myocardial infarction (MI) and briefly discuss the applicability of current management strategies for MI in the context of PV.

\section{Case Report}

Patient is a 73-year-old white male presented to the emergency department with sudden onset of severe chest pain. He reported history of hypertension and hyperlipidemia but denied use of tobacco or recreational drugs. On admission, physical examination was unremarkable except for splenomegaly. Laboratory data was significant for hemoglobin of $22 \mathrm{~g} / \mathrm{dl}$, hematocrit of $66 \%$, and peak troponin of 4.3 $\mathrm{ng} / \mathrm{ml}$. White cell count was $9.6 \times 10^{3} / \mathrm{dl}$, platelet count was $357 \times$ $10^{3} / \mathrm{dl}$ and biochemistry panel was normal. Electrocardiogram showed mild ST depression in the inferior leads. Echocardiogram was normal without regional wall motion abnormalities and an ejection fraction of 50-55\%. Overall, the clinical picture was consistent with non-ST elevation myocardial infarction and treatment with aspirin, heparin, metoprolol, simvastatin and lisinopril was initiated. Subsequent coronary angiography showed diffuse three-vessel disease and cardio thoracic surgery was consulted for coronary bypass surgery (CABG). Hematology consult was sought in view of polycythemia and further evaluation confirmed polycthemia rubra vera (low erythropoietin JAK-2 mutation positive and massive splenomegaly). He was treated with intermittent phlebotomy and volume replacement. Three-vessel coronary artery bypass graft (CABG) was done once hematocrit less than $45 \%$. Peri- and post-operative course was uncomplicated and he was discharged with recommendations of long-term intermittent phlebotomy apart from aspirin, statin and beta-blocker. He was scheduled to follow up with hematology for further consideration of myelosuppressive agents.

\section{Discussion}

PV is a myeloproliferative neoplasm characterized by clonal proliferation of myeloid cells with predominant elevation in red cell mass. The most common complications of PV include thrombosis, bleeding and transformation to myelofibrosis or leukemia. The thrombotic events could be both arterial and venous. It is often diagnosed incidentally on a routine laboratory testing prior to a major thrombotic event. However, myocardial infarction as the initial manifestation of PV as in our patient is unusual [2-9]. Although hyper viscosity is commonly considered to be the major pathogenic mechanism for arterial thrombotic complications in PV, a significant number of patients have other risk factors like smoking, hypertension, arguing strongly in favor of additive risk and shared pathogenesis [10].

Cytoreductive treatment with phlebotomy to achieve a goal hematocrit of $45 \%$ is crucial in optimizing the outcomes in patients with PV [11]. The role of low dose aspirin in preventing thrombotic complications in PV is well known [12]. The patients with age greater than 60 years and prior history of thrombosis are considered high risk for thrombotic events and are often treated with additional myelosuppressive agents such as hydroxyurea. Recently ruxolitinib, a JAK1/2 inhibitor was also approved to treat these patients.

There is no standard consensus on management of acute MI in patients with PV. In one study, standard anti platelet therapy combined with recurrent phlebotomy reduced the risk of re-infarction by $70 \%$ in patients with acute coronary syndrome [13]. In patients with PV presenting with acute coronary syndrome, it was reviewed that cytoreductive therapy along with aspirin provided greatest benefit in mortality reduction with a minimal risk for bleeding [14]. Few studies suggested the use of anticoagulants such as warfarin along with antiplatelet agents will help prevent recurrent thrombosis $[8,15,16]$. However, the effectiveness of clopidogrel, glycoprotein IIb-IIIa inhibitors and intervention with coronary stents or CABG has not been rigorously studied in patients with PV.

Percutaneous coronary intervention (PCI) is the standard of care for treatment of acute MI. Nevertheless, patients with PV presenting with acute MI due to underlying hyperviscocity are reportedly associated with acute aortic occlusion and recurrent stent thrombosis despite appropriate antiplatelet therapy [17-19]. Surgery in patients with PV was notably associated with increased morbidity and mortality. The post-operative mortality was four times higher in patients with elevated hematocrit prior to surgery [17]. It is therefore important to consider pre-procedure phlebotomy to achieve a goal hematocrit of $45 \%$ whenever possible. There is limited data on use of other revascularization methods such as fibrinolysis or coronary artery bypass surgery in these patients [3,7,8]. A brief review on the management of acute MI in patients with PV from published case reports in english literature is shown in Table 1 . The ideal revascularization strategy in terms of PCI versus CABG remains elusive in these patients. Studies showed that even with adequate control of blood counts in PV patients, thrombotic risk can only be decreased but couldn't be totally ameliorated [17]. 
Citation: Thota R (2015) Therapeutic Challenges in the Management of Acute Myocardial Infarction in Polycythemia Vera. J Blood Disorders Transf 6: 253. doi:10.4172/2155-9864.1000253

Page 2 of 3

\begin{tabular}{|c|c|c|c|c|c|c|c|c|c|c|}
\hline Study & $\begin{array}{l}\text { Agel } \\
\text { Sex }\end{array}$ & Presentation & НСТ & $\begin{array}{l}\text { Initial } \\
\text { Treatment }\end{array}$ & $\mathrm{PCl}$ finding & Intervention & $\begin{array}{l}\text { Post-op } \\
\text { treatment }\end{array}$ & $\begin{array}{l}\text { Long term } \\
\text { treatment }\end{array}$ & Outcome & Remarks \\
\hline $\begin{array}{l}\text { Vengoni et } \\
\text { al. [9] }\end{array}$ & $66 / F$ & STEMI & $57 \%$ & $\begin{array}{l}\text { Aspirin } \\
\text { Phlebotomy } \\
\text { Heparin }\end{array}$ & $\begin{array}{l}\text { Occlusive } \\
\text { thrombus in } \\
\text { proximal } \\
\text { LAD }\end{array}$ & $\begin{array}{lr}\text { Urokinase } & 500, \\
000 & \text { units } \\
\text { followed } & \text { by } \\
\text { PTCA } & \end{array}$ & $\begin{array}{l}\text { Within } \\
\text { hours } \\
\text { developed } \\
\text { refractory } \\
\text { cardiogenic } \\
\text { shock }\end{array}$ & Not reported & Dead & $\begin{array}{lr}\text { Hematocrit } & 41 \% \\
\text { prior to first } & \mathrm{PCl} \text {. } \\
\text { Repeat } & \mathrm{PCl} \\
\text { showed } & \text { no } \\
\text { thrombosis. } & \end{array}$ \\
\hline $\begin{array}{l}\text { Bahbahani } \\
\text { et al. [3] }\end{array}$ & $37 / M$ & STEMI & $50 \%$ & $\begin{array}{l}\text { Aspirin Plavix } \\
\text { Lovenox }\end{array}$ & $\begin{array}{l}\text { Not } \\
\text { performed } \\
\text { due to lack } \\
\text { of availability } \\
\text { in that facility }\end{array}$ & $\begin{array}{l}\text { Reteplase } 10 \\
\text { units bolus, } \\
\text { then } 10 \text { units } \\
\text { given } \\
\text { intravenously } \\
\text { over } 30 \text { min, }\end{array}$ & - & \begin{tabular}{|l} 
Aspirin \\
Hydroxyurea \\
Phlebotomy
\end{tabular} & Alive & $\begin{array}{l}\text { Myocardial } \\
\text { perfusion } \\
\text { scintigraphy one } \\
\text { month later was } \\
\text { normal }\end{array}$ \\
\hline $\begin{array}{l}\text { Osada et al. } \\
\text { [7] }\end{array}$ & $65 / M$ & Stable angina & $59 \%$ & 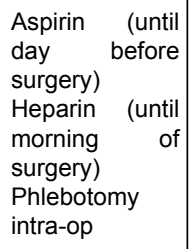 & $\begin{array}{l}\text { Proximal } \\
\text { LAD showed } \\
99 \% ; \quad \text { Mid } \\
\text { LAD showed } \\
75 \% \quad \text { OM } \\
\text { showed } 90 \% \\
\text { stenoses }\end{array}$ & CABG & $\begin{array}{l}\text { Post op day } 1 \\
\text { developed } \\
\text { STEMI. PCI } \\
\text { showed } \\
\text { thrombosis of } \\
\text { native and } \\
\text { graft as well } \\
\text { s/p PTCA }\end{array}$ & $\begin{array}{l}\text { Aspirin Plavix } \\
\text { Warfarin }\end{array}$ & Alive & \\
\hline Oz et al. [8] & $46 / M$ & $\begin{array}{l}\text { Unstable } \\
\text { angina }\end{array}$ & $47 \%$ & $\begin{array}{l}\text { Aspirin } \\
\text { Phlebotomy }\end{array}$ & $\begin{array}{l}\text { LAD showed } \\
80-90 \% \quad ; \\
\text { LCX showed } \\
70 \% \text { RCA } \\
\text { showed } 80 \% \\
\text { stenoses }\end{array}$ & CABG & $\begin{array}{l}\text { Heparin in } \\
\text { early post op } \\
\text { period }\end{array}$ & $\begin{array}{l}\text { Aspirin, Plavix, } \\
\text { Warfarin }\end{array}$ & Alive & $\begin{array}{l}\text { Diagnosed with } \\
\text { PV } \sim 2 \text { years } \\
\text { prior. Hematocrit } \\
\text { was } 42 \% \text { prior to } \\
\text { CABG }\end{array}$ \\
\hline Oz et al. [8] & $61 / F$ & $\begin{array}{l}\text { Stable angina } \\
\text { positive stress } \\
\text { test }\end{array}$ & $40 \%$ & $\begin{array}{l}\text { Aspirin } \\
\text { Hydroxyurea }\end{array}$ & $\begin{array}{l}\text { LAD showed } \\
80 \% \quad \text { RCA } \\
\text { showed } 90 \% \\
\text { stenoses }\end{array}$ & CABG & $\begin{array}{l}\text { Heparin in } \\
\text { early post op } \\
\text { period }\end{array}$ & \begin{tabular}{|l} 
Aspirin, \\
Plavix, \\
Warfarin \\
Hydroxyurea
\end{tabular} & Alive & $\begin{array}{l}\text { On treatment for } \\
P V \sim 3 \text { years } \\
\text { prior }\end{array}$ \\
\hline Wu et al. [2] & $34 / M$ & STEMI & $65 \%$ & $\begin{array}{l}\text { Aspirin Plavix } \\
\text { Heparin } \\
\text { Phlebotomy }\end{array}$ & $\begin{array}{l}\text { Mid LAD } \\
60 \% \\
\text { occlusion } \\
\text { with a distal } \\
\text { thrombotic } \\
\text { occlusion }\end{array}$ & No intervention & Phlebotomy & Not reported & Alive & $\begin{array}{l}\text { Discharged with } \\
\text { hematology } \\
\text { follow up }\end{array}$ \\
\hline $\begin{array}{l}\text { Chan et al. } \\
\text { [4] }\end{array}$ & $42 / \mathrm{M}$ & $\begin{array}{l}\text { Unstable } \\
\text { angina }\end{array}$ & $71 \%$ & $\begin{array}{l}\text { Aspirin, } \\
\text { Heparin, } \\
\text { phlebotomy }\end{array}$ & $\begin{array}{l}\text { LAD } \\
\text { thrombosis } \\
\text { distal to } \\
\text { perforating } \\
\text { branches } \\
\text { otherwise } \\
\text { normal } \\
\text { coronaries }\end{array}$ & No intervention & - & Warfarin & Alive & $\begin{array}{l}\text { On day } 7 \text { echo } \\
\text { showed large } \\
\text { intraventricular } \\
\text { thrombus }\end{array}$ \\
\hline $\begin{array}{l}\text { Hermanns } \\
\text { et al. [6] }\end{array}$ & $30 / M$ & Acute MI & $61 \%$ & - & $\begin{array}{l}\text { Not } \\
\text { performed }\end{array}$ & $\begin{array}{l}\text { Tissue } \\
\text { plasminogen } \\
\text { activator } 100 \\
\mathrm{mg} / 2 \mathrm{hr}\end{array}$ & $\begin{array}{l}\text { Developed } \\
\text { refractory } \\
\text { cardiogenic } \\
\text { shock failed } \\
\text { resuscitation }\end{array}$ & & Dead & $\begin{array}{l}\text { Autopsy showed } \\
\text { no evidence of } \\
\text { atherosclerosis } \\
\text { but marked } \\
\text { intimal } \\
\text { proliferation } \\
\text { noted }\end{array}$ \\
\hline
\end{tabular}

Table: 1: Information from published case reports on management of coronary artery disease and polycythemia vera.

HCT: Hematocrit on Presentation; PCI: Percutaneous Coronary Intervention; F: Female; M: Male; PV: Polycythemia Vera; MI: Myocardial Infarction; STEMI: ST Elevation Myocardial Infarction; LAD: Left anterior descending artery; LCX: Left circumflex artery; RCA: Right coronary artery; OM: Obtuse Marginal; PTCA: Percutaneous Transluminal Coronary Angiography; CABG: Coronary Artery Bypass Graft.

\section{Conclusion}

The management of patients with PV presenting with acute MI is complex. The initial treatment should focus on cytoreductive treatment prior to proceeding with intervention. The superior revascularization strategy (PCI versus $\mathrm{CABG}$ ) and adequate antithrombotic therapy (single or dual antiplatelet therapy $+/$ - anticoagulants) needs further investigation. It is important to consider adequate use of 
Citation: Thota R (2015) Therapeutic Challenges in the Management of Acute Myocardial Infarction in Polycythemia Vera. J Blood Disorders Transf 6: 253. doi:10.4172/2155-9864.1000253

Page 3 of 3

myelosuppressive agents such as hydroxyurea or ruxolitinib in high risk patients to prevent future thrombotic events.

\section{References}

1. Passamonti F, Rumi E, Pungolino E, Malabarba L, Bertazzoni P, et al. (2004) Life expectancy and prognostic factors for survival in patients with polycythemia vera and essential thrombocythemia. Am J Med 117: 755-761.

2. Wu CF, Armstrong GP, Henderson RA, Ruygrok PN (2005) Polycythaemia vera presenting as ST-elevation myocardial infarction. Heart Lung Circ 14 51-53.

3. Bahbahani H, Aljenaee K, Bella A3 (2015) Polycythemia vera presenting as acute myocardial infarction: An unusual presentation. J Saudi Heart Assoc 27: 57-60.

4. Chan AW, Drobac M, Sternberg L (1997) The management of acute myocardial infarction in a patient with polycythemia rubra vera during the thrombolytic era--does it make a difference? Can J Cardiol 13: 59-63.

5. Goethals P, Evrard S, Dubois C (2000) Recurrent coronary stent thrombosis. Acta Cardiol 55: 371-373.

6. Hermanns B, Handt S, Kindler J, Füzesi L (1998) Coronary vasculopathy in polycythemia vera. Pathol Oncol Res 4: 37-39.

7. Osada H, Nakajima H, Meshii K, Ohnaka M2 (2014) Acute coronary artery bypass graft failure in a patient with polycythemia vera. Asian Cardiovasc Thorac Ann

8. Oz BS, Asgun F, Akay HT, Kaya E, Kuralay E, et al. (2007) Anticoagulation after coronary artery surgery in patients with polycythemia vera: report of two cases. J Card Surg 22: 420-422.

9. Venegoni P, Schroth G (1994) Myocardial infarction and polycythemia vera: how should we treat it? Cathet Cardiovasc Diagn 32: 259-261.
10. Ganti AK, Potti A, Koka VK, Pervez H, Mehdi SA (2003) Myeloproliferative syndromes and the associated risk of coronary artery disease. Thromb Res 110: 83-86.

11. Marchioli R, Finazzi G, Specchia G, Cacciola R, Cavazzina R, et al. (2013) Cardiovascular events and intensity of treatment in polycythemia vera. $\mathrm{N}$ Engl J Med 368: 22-33

12. Landolfi R, Marchioli R, Kutti J, Gisslinger H, Tognoni G, et al. (2004) Efficacy and safety of low-dose aspirin in polycythemia vera. N Engl J Med 350: 114-124.

13. De Stefano V, Za T, Rossi E, Vannucchi AM, Ruggeri M, et al. (2008) Recurrent thrombosis in patients with polycythemia vera and essential thrombocythemia: incidence, risk factors, and effect of treatments. Haematologica 93: 372-380.

14. Willoughby S, Pearson TC (1998) The use of aspirin in polycythaemia vera and primary thrombocythaemia. Blood Rev 12: 12-22.

15. Bachleitner-Hofmann T, Grumbeck E, Gisslinger H (2003) Oral anticoagulants as secondary prophylaxis of thrombosis in patients with polycythemia vera: a retrospective analysis of 15 patients. Thromb Res 112: 229-232.

16. Ural AU, Cetin T, Avcu F (2008) Antithrombotic challenges after coronary artery surgery in patients with polycytemia vera. J Card Surg 23: 410.

17. Wasserman LR, Gilbert HS (1963) Surgery In Polycythemia Vera. N Engl J Med 269: 1226-1230.

18. Zavalloni D, Marsico F, Milone F, Presbitero P (2004) Is conventional antiplatelet therapy for the prevention of coronary stent thrombosis always safe? A case report of a patient with polycythemia vera. Ital Heart J 5: 163-166.

19. Zinn P, Applegate RJ, Walsh RA (1988) Acute total aortic occlusion during cardiac catheterization associated with polycythemia vera. Cathet Cardiovasc Diagn 14: 108-110. 